\title{
Рівні ендотеліну-1 та тестостерону в крові хворих на цүкровий діабет 1-го та 2-го типів
}

\section{Є.В. Лучицький, Л.К. Соколова, В.Є. Лучицький, Ю.Б. Бєльчина,} Г.А. Зубкова, С.А. Червякова, В.М. Рибальченко, В.В. Пушкарьов, Т.С. Вацеба, I.І. Складанна, B.M. Пушкарьов

ДУ «Інститут ендокринології та обміну речовин ім. В.П. Комісаренка НАМН України»

Резюме. Із цукровим діабетом (ЦД) пов'язана ендотеліальна дисфункція (ЕД) - одна з ключових патологічних подій у розвитку хронічних діабетичних ускладнень. Важливим ефектом ЕД є збільшення продукції та біологічної активності ендотеліну (ЕТ). ЕТ-1, який виробляється переважно в ендотелії, є основною серцево-судинною ізоформою ендотелінової системи. ЦД - одне із захворювань, пов'язаних із патологічно підвищеним рівнем ЕТ. Отримані докази того, що андрогени можуть грати певну роль у визначенні специфічного для статі артеріального тиску. Чоловіки мають більш високий ризик розвитку ішемічної хвороби серця або гіпертонічної хвороби порівняно з жінками в пременопаузі. Мета - визначення концентрації ЕТ-1 та тестостерону (Т) в крові хворих на цукровий діабет першого (ЦД1) та другого (ЦД2) типів із різним індексом маси тіла (IMT) та різних вікових категорій. Матеріал і методи. Рівень ЕТ-1 оцінювали методом ІФА в 103 осіб: 17 здорових осіб та 86 пацієнтів із ЦД1 і ЦД2. Для визначення концентрації ЕT-1 використовували набір Endotelin (1-21) ElA. Загальний Т визначали за допомогою набору EIA-1559. Результати. У всіх пацієнтів із діабетом рівень ЕT-1 у крові був значно вищим, ніж в осіб контрольної групи. Різниця в кількості ЕТ-1 у крові пацієнтів із ЦД1 і ЦД2 була невірогідною. Рівень ЕТ-1 у чоловіків був вищим, ніж у жінок у середньому на 37\%. У групі 3 вищим індексом маси тіла кількість ЕТ-1 була вищою на 71\%, а Т — нижчою на 25\%. Рівень ЕT-1 у віковій групі до 50 років був нижчим, ніж у старшій групі для обох типів ЦД (123\% для ЦД1 і 148\% для ЦД2), а кількість Т у хворих на ЦД2 - вища майже на 20\%. У групі хворих на ЦД2 з рівнем Т<3 нг/мл концентрація ЕТ-1 у крові була вищою, ніж у хворих із рівнем Т>3 нг/мл (відповідно 0,550 фмоль/мл і 0,392 фмоль/мл). Висновки. У чоловіків, хворих на ЦД2 з ожирінням спостерігається підвищення концентрації ЕТ-1 і зниження рівня Т. Ці показники, напевно, безпосередньо не пов'язані з вмістом глікованого гемоглобіну (Нв1Ас). Із віком рівень ЕТ-1 у крові хворих на ЦД зростає, а рівень Т знижується. Ці процеси можуть бути взаємопов'язаними. Концентрація ЕТ-1 у крові в чоловіків, хворих на ЦД обох типів вірогідно вища, ніж у жінок.

Ключові слова: цукровий діабет, ендотеліальна дисфункція, ендотелін-1, тестостерон.

\footnotetext{
* Адреса для листування (Correspondence): ДУ «Інститут ендокринології та обміну речовин ім. В.П. Комісаренка НАМН України», вул. Вишгородська, 69, м. Київ, 04114 , Україна. E-mail: pushkarev.vm@gmai.com 
Згідно сучасних класифікацій (ADA, 2020) виділяють ЦД1 (через автоімунну деструкцію $\beta$-клітин, що зазвичай призводить до абсолютного дефіциту інсуліну), ЦД2 (через прогресуючу втрату секреції інсуліну $\beta$-клітин часто на тлі інсулінорезистентності), гестаційний ЦД та специфічні типи діабету, зумовлені іншими причинами. Із діабетом пов'язана ЕД, яка є однією з ключових патологічних подій у розвитку хронічних діабетичних ускладнень [1, 2]. ЕД - це системний патологічний стан ендотелію, який визначається як дисбаланс між судинорозширювальними та судинозвужувальними речовинами, що виробляються ендотелієм. Важливим ефектом ЕД є те, що вона призводить до збільшення продукції та біологічної активності потужного судинозвужувального та прозапального пептидного ЕТ. ЦД - одне із захворювань, пов'язаних із патологічно підвищеним рівнем ЕT [3].

ЕТ-1 є основною серцево-судинною ізоформою ендотелінової системи. Судинний ЕT-1 виробляється в основному в ендотелії, хоча він також може вироблятися в клітинах гладкої мускулатури судин, макрофагах, лейкоцитах, кардіоміоцитах і фібробластах. У кліренсі ЕТ-1 у плазмі крові задіяно кілька механізмів, що включають ендоцитоз у легенях, ферментативну деградацію, деградацію комплексу ендотелін-В-рецептор, ферментативні процеси в нирках і печінці $[4,5]$. Два підтипи рецепторів, А- та В-рецептори ЕТ, опосередковують ефекти ЕТ-1. Клітини гладкої мускулатури судин експресують як А-рецептори, так i В-рецептори, тоді як клітини ендотелію експресують насамперед В-рецептори. У клітинах гладкої мускулатури А-рецептори опосередковують вазоконстрикцію та мітогенез, тоді як В-рецептори мають подвійну функцію і можуть викликати звуження і розширення судин [6]. Зміна балансу ендотелію ЕТ-1 є ключовою подією при виникненні атеросклерозу [7].

Є вагомі докази того, що андрогени можуть грати певну роль у визначенні специфічного для статі артеріального тиску. Чоловіки мають більш високий ризик розвитку ішемічної хвороби серця або гіпертонічної хвороби порівняно $з$ жінками в пременопаузі. Однак вплив андрогенів на ниркову та серцево-судинну систему є неоднозначним. Гостре введення Т знижує судинний тонус, проте довгостроковий ефект андрогенів сприяє вазоконстрикції за рахунок uр-регуляції експресії тромбоксану A2, синтезу норадреналіну, експресії ангіотензину II і дії ЕТ-1. Крім того, андрогени викликають серцеву гіпертрофію, сприяють атеросклерозу, ремоделюванню судин і стимулюють прогіпертензивні процеси в нирках за участю системи ренін-ангіотензин-альдостерон.

Епідеміологічні, клінічні та експериментальні дослідження показали, що андрогени можуть бути важливими факторами, що визначають статеві відмінності артеріального тиску. У деяких дослідженнях було встановлено зв'язок між нижчим рівнем Т у чоловіків та гіпертонією, ішемічною хворобою або інфарктом міокарда [8].

Мета роботи - визначення концентрації ET-1 і Т у крові хворих на ЦД1 і ЦД2 з різним індексом маси тіла та різних вікових категорій.

\section{Матеріал і методи}

Рівень ЕТ-1 оцінювали методом імуно-ферментного аналізу в 103 осіб: 17 здорових осіб та 86 пацієнтів із Цд1 і ЦД2. Протокол дослідження було затверджено комітетом 3 етики ДУ «Інститут ендокринології та обміну речовин ім. В.П. Комісаренка НАМН України». Усі учасники надали письмову інформовану згоду на використання своїх біоматеріалів для подальших досліджень та діагностики. Кров отримували за допомогою стандартної венепункції та зберігали у вакуумних пробірках з EDTA. Плазму відокремлювали центрифугуванням протягом 10 хв після забору крові. Зразки зберігали при $-80{ }^{\circ} \mathrm{C}$ до використання. Концентрацію ЕТ-1 визначали за допомогою набору «Endotelin (1-21) EIA» («Biomedica», Австрія) при оптичній щільності 450 нм, концентрацію загального T - за допомогою набору «EIA-1559 («DRG Instruments» $\mathrm{GmbH»,} \mathrm{Німеччина),} \mathrm{концентрацію} \mathrm{Нв1Ac} \mathrm{-} \mathrm{за}$ допомогою набору «оne HbA1c FS» («DiaSys Diagnostic Systems GmbH», Німеччина) при оптичній щільності 660 нм.

Статистичні розрахунки та представлення даних проводилися за допомогою програмного забезпечення Origin 7.0. Результати дослідження представлені у вигляді $\mathrm{M} \pm \mathrm{Std}$. Для порівняння груп даних використовували t-тест Стьюдента та one-way ANOVA. Значення $\mathrm{p}<\mathrm{d} 0,05$ вважалися вірогідними. 


\section{Результати та обговорення}

У всіх пацієнтів із ЦД рівень ЕТ-1 у крові був вищим, ніж у осіб контрольної групи. Середня концентрація ЕТ-1 у крові хворих на ЦД $(\mathrm{n}=86)$ становила 5,36 $\pm 0,47$ фмоль/мл

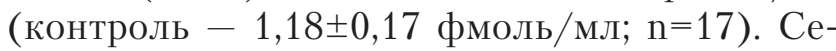
редній рівень Нв1Ас у крові хворих на ЦД

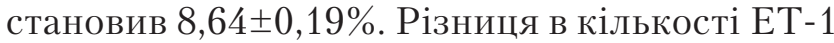
у крові пацієнтів із ЦД1 і ЦД2 була невірогідною (рис.). Водночас, спостерігались вірогідні гендерні відміни як для ЦД1, так і для ЦД2. Рівень ЕT-1 у чоловіків був вищим, ніж у жінок.

Встановлено, що в здорових чоловіків рівень ЕТ-1 також вищий порівняно з жінками в середньому на 37\%. Очевидно, таке співвідношення має місце і у хворих на ЦД обох типів. Відомо, що статевий диморфізм щодо артеріального тиску розвивається в пубертатному періоді і зберігається в зрілому віці. Систолічний артеріальний тиск у чоловіків молодше 60 років на 6-7 мм рт. ст. був вищим порівняно 3 жінками, діастолічний АТ підвищений приблизно на 3-5 мм рт. ст. [9]. Можливо такий диморфізм пов'язаний і з рівнем ЕТ-1.

Важливими показниками для ЦД2 є вік пацієнта, IMT та рівень Нв1Ас у крові. Дані іншої групи пацієнтів було проаналізовано

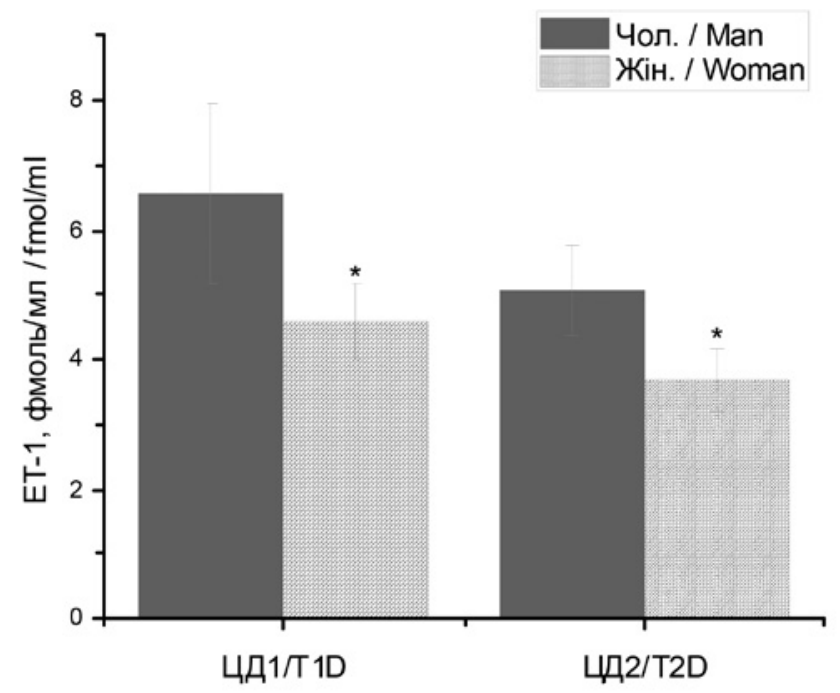

Рис. Рівень ЕТ-1 у крові в жінок та чоловіків, хворих на ЦД1 і ЦД2. 1 - ЦД1 ( $n=28), 2$ - ЦД2 $(n=58)$ * — відмінності між показниками чоловіків і жінок вірогідні, p<0,05.

Fig. The level of ET-1 in the blood of women and men with type 1 and 2 diabetes. 1 - Type 1 diabetes $(n=28), 2$ - Type 2 diabetes $(n=58) .{ }^{*}$ - differences between the indicators of men and women are significant, $\mathrm{p}<0,05$. з урахуванням цих показників. Отримані дані показують, що за рівнем Нв1Ас групи вірогідно не відрізнялися. У групі з вищим IMT концентрація ЕТ-1 була вищою на 71\%, а концентрація Т - нижчою на 25\% (табл. 1 ).

Рівень ЕТ-1 у віковій групі до 50 років був нижчим за відповідний показник у старшій групі для обох типів ЦД (123\% для ЦД1 і 148\% для ЦД2), а концентрація Т у крові у хворих на ЦД2 - вища майже на 20\% (табл. 2). У групі хворих на ЦД2 з рівнем $\mathrm{T}<3$ нг/мл концентрація ЕТ-1 у крові була вищою за відповідний показник у хворих із рівнем Т>3 нг/мл (відповідно 5,50 фмоль/мл і 3,92 фмоль/мл).

Таблиця 1. Рівень ЕТ-1 та Т у крові чоловіків із ЦД2 в залежності від IMT та кількості Нв1Ас

Table 1. The level of ET-1 and T in the blood of men with type 2 diabetes depending on body weight index and the amount of glycated hemoglobin

\begin{tabular}{llll}
\hline № & $\begin{array}{l}\text { Показники } \\
\text { N }\end{array}$ & $\begin{array}{l}\text { 1-a група } \\
\text { Indicators }\end{array}$ & $\begin{array}{l}\text { 2-a група } \\
\text { 2nd group }\end{array}$ \\
\hline 1 & IMT (бали) & $26,82 \pm 0,49$ & $34,0 \pm 0,70^{*}$ \\
& ВМІ (points) & & \\
2 & Нв1АС (\%) & $8,38 \pm 0,384$ & $8,46 \pm 0,34$ \\
3 & ЕT-1 (фмоль/мл) & $2,91 \pm 0,017$ & $4,99 \pm 0,041^{*}$ \\
& ЕT-1 (fmol/ml) & $(\mathrm{n}=12)$ & $(\mathrm{n}=22)$ \\
4 & Т (нг/мл) & $4,92 \pm 0,143$ & $3,66 \pm 0,113^{*}$ \\
& Т (ng/ml) & $(\mathrm{n}=18)$ & $(\mathrm{n}=17)$ \\
\hline
\end{tabular}

Примітка: порівнювались показники двох груп із різними IMT. * - відміни між групами вірогідні $(p<0,05)$.

Note: the indicators of the two groups with different body weight index were compared. ${ }^{*}$ - differences between groups are significant $(p<0,05)$.

Таблиця 2. Рівень ЕТ-1 і Т у крові хворих на ЦД1 і ЦД2 з урахуванням віку.

Table 2. Levels of ET-1 and T in the blood of patients with type 1 and 2 diabetes, taking into account age.

\begin{tabular}{|c|c|c|c|c|}
\hline $\begin{array}{l}\text { № } \\
\text { N }\end{array}$ & $\begin{array}{l}\text { Вік } \\
\text { Age }\end{array}$ & $\begin{array}{l}\text { Тип діабету } \\
\text { Diabetes } \\
\text { type }\end{array}$ & $\begin{array}{l}\text { ЕT-1 } \\
\text { (фмоль/мл) } \\
\text { (fmol/ml) }\end{array}$ & $\begin{array}{l}\text { T } \\
\text { (нг/мл) } \\
\text { (ng/ml) }\end{array}$ \\
\hline \multirow[t]{2}{*}{1} & $<50$ років & ЦД1 (n=27) & $4,26 \pm 0,43$ & $5,04 \pm 0,12$ \\
\hline & & ЦД2 (n=17) & $3,67 \pm 0,37$ & $4,86 \pm 0,24$ \\
\hline \multirow[t]{2}{*}{2} & $>50$ років & ЦД1 (n=12) & $5,23 \pm 0,48^{*}$ & - \\
\hline & & ЦД2 (n=38) & $5,43 \pm 0,71^{*}$ & $4,0 \pm 0,40^{*}$ \\
\hline
\end{tabular}

Примітка: * - відмінності від групи 1 для відповідного типу ЦД вірогідні $(p<0,05)$. Кількість хворих на ЦД1 віком понад 50 років була недостатньою для аналізу концентрації $T$.

Note:* - differences from group 1 for the corresponding type of diabetes are significant $(p<0,05)$. The number of patients with diabetes mellitus 1 over the age of 50 years was insufficient to analyze the concentration of $T$. 
Молекулярні механізми впливу патологічних факторів на секрецію ЕТ-1 при ЦД ще недостатньо вивчені. ЕТ-1 постійно синтезується і секретується ендотеліальними клітинами. Він локалізується в клітинах ендотелію, як у конститутивних секреторних везикулах, так і в спеціалізованих регуляторних гранулах - тільцях Вайбеля-Паладе [10, 11]. Деякі агенти підвищують вміст ЕТ-1 за рахунок екзоцитозу тілець Вайбеля-Паладе, а також шляхом стимуляції експресії мРНК гена $e d n 1$. Рівні ЕТ-1 модулюються переважно на рівні транскрипції, до чого залучені численні транскрипційні фактори, включаючи білок активатор-1 (AP-1), ядерний фактор каппа В (NF$\kappa \mathrm{B})$, FOXO1 (forkhead box protein O1), VezF1 (vascular endothelial zinc finger 1), фактор, індукований гіпоксією-1 (HIF-1) i GATA-2. Одним із найважливіших регуляторів продукції ET-1 в ендотеліальних клітинах є трансформуючий фактор росту- $\beta$ [12].

При високому IMT ожиріння генерує гіпертрофічні сигнали, включаючи експресію i самого ЕT-1, який стимулює дію GATA-4. Сигнальний шлях, очевидно, включає активацію RhoA i p38-мітоген-активованої протеїнкінази (МАРК) і врешті-решт призводить до фосфорилювання та активації GATA-4. Лептин, який секретується переважно жировими клітинами і концентрація якого збільшується 3 ожирінням, також стимулює експресію ET-1 через c-Jun-N-термінальну кіназу, кіназу, що регулюється позаклітинними факторами (ERK1/2) та гетеродимер c-Fox/c-Jun (білокактиватор-1). Жирні кислоти та ліпопротеїни підсилюють експресію ЕТ-1 через протеїнкіназу $\mathrm{C}$, яка може активувати як білок-активатор-1, так і ядерний фактор каппа В - ключовий чинник, який інтегрує в клітині зовнішні прозапальні сигнали і реалізує їх ефект при ЦД та атеросклерозі [2, 11]. Нарешті, хронічне запалення низького рівня, яке виникає при ожирінні та ЦД2, і пов’язане з секрецією прозапальних факторів, таких як фактор некрозу пухлини- $\alpha$, інтерлейкін-1 $\beta$ та інтерферон- $\gamma$, також активує ядерний фактор каппа В через сигнальний шлях фосфоінозитид-3-кіназа/ $\mathrm{Akt} / \mathrm{I \kappa B}$-кіназний комплекс із подальшою експресією ЕТ-1 [10].

Ендотелін-1 - один із найпотужніших судинозвужувальних засобів, який здійснює різні паракринні та ендокринні ефекти на репродуктивну систему чоловіка. Він здатний впливати на стероїдогенез у клітинах Лейдіга і стимулювати секрецію Т. Вважається, що вплив статевих гормонів на судинну реактивність є одним з основних факторів, що сприяють гендерним відмінностям серцево-судинної функції та захворювань [13]. Зниження рівня Т може бути передвісником погіршення здоров'я - гіпогонадизм пов'язаний із підвищеним ризиком виникнення серцево-судинних захворювань [14, 15]. Чоловіки з гіпогонадизмом мають майже вдвічі більший ризик смертності, ніж чоловіки 3 нормальним рівнем Т [16]. Зворотна залежність між рівнем Т у плазмі крові та ризиком серцево-судинних захворювань спостерігалась для 9 із 10 серцево-судинних маркерів: ЕT-1, серцевий тропонін I (cTnI), інтерлейкін-6, фактор некрозу пухлини- $\alpha$, натрійуретичний гормон мозку, ліпопротеїди високої щільності, високочутливий C-реактивний білок (hsCRP), HbA1c та лептин. Отже, у чоловіків із низьким рівнем Т у плазмі крові спостерігається зростання кардіоваскулярних показників ризику, що відповідає потенційному підвищеному ризику виникнення серцево-судинних захворювань [17, 18].

Даних щодо впливу Т на судини та взаємодії між статевими гормонами і ЕТ недостатньо. Базальний рівень ЕТ-1 у пацієнтів із гіпогонадизмом був значно вищим порівняно з показником у контрольній групі [9]. Після замісної терапії Т рівень ЕТ-1 у крові в пацієнтів цієї групи знизився на 27\% на третьому і на $30 \%$ на шостому місяці прийому препарату відповідно. Ці результати показують, що рівень ЕТ-1 у плазмі в чоловіків із гіпогонадизмом підвищений, але $з$ тенденцією до зниження після прийому Т.

Зниження рівня Т у чоловіків старших вікових груп, можливо, призводить до підвищення вмісту ЕТ-1, і це може зумовлювати підвищений ризик розвитку серцево-судинних захворювань.

\section{Висновки}

1. У чоловіків, хворих на цукровий діабет 2-го типу 3 ожирінням спостерігається підвищення концентрації ендотеліну-1, та зниження рівня тестостерону. Ці показники, 
напевно, безпосередньо не пов'язані з вмістом глікованого гемоглобіну.

2. Із віком рівень ендотеліну-1 у крові у хворих на цукровий діабет зростає, а рівень тестостерону знижується. Ці процеси можуть бути взаємопов'язаними.

3. Концентрація ендотеліну-1 у крові в чоловіків, хворих на цукровий діабет обох типів вірогідно вища, ніж у жінок.

\section{Список використаної літератури}

1. Тронько НД, Пушкарев ВМ, Соколова ЛК, Пушкарев ВВ, Ковзун ЕИ. Молекулярные механизмы патогенеза сахарного диабета и его осложнений. К.: Издательский дом Медкнига, 2018. 264 с. (Tronko ND, Pushkarev VM, Sokolova LC, Pushkarev VV, Kovzun EI. Molecular mechanisms of the pathogenesis of diabetes mellitus and its complications. K.: Medkniga Publishing House, 2018. 264 p.).

2. Соколова ЛК, Пушкарев ВМ, Пушкарев ВВ, Ковзун ЕИ, Тронько НД. Диабет и атеросклероз. Роль процессов воспаления в патогенезе. Обзор литературы. Міжнародний ендокринологічний журнал. 2017;13(7):486-98. (Sokolova LK, Pushkarev VM, Pushkarev VV, Kovzun OI, Tronko MD. Diabetes mellitus and atherosclerosis. The role of inflammatory processes in pathogenesis. Int J Endocrinol. 2017;13(7):486-98.).

3. Jain A, Chen S, Yong H, Chakrabarti S. Endothelin-1 traps potently reduce pathologic markers back to basal levels in an in vitro model of diabetes. J Diabetes Metab Disord. 2018;17(2):189-95.

4. Johnström P, Fryer TD, Richards HK, Maguire JJ, Clark JC Pickard JD, et al. Positron emission tomography of [18F]-big endothelin-1 reveals renal excretion but tissue-specific conversion to [18F]-endothelin-1 in lung and liver. $\mathrm{Br} \mathrm{J}$ Pharmacol. 2010;15990(4):812-9.

5. Johnström P, Fryer TD, Richards HK, Harris NG, Barret O, Clark JC, et al. Positron emission tomography using 18F-labelled endothelin-1 reveals prevention of binding to cardiac receptors owing to tissue-specific clearance by ET B receptors in vivo. Br J Pharmacol. 2005;144(1):115-22.

6. Kalani M. The importance of endothelin-1 for microvascular dysfunction in diabetes. Vasc Health Risk Manag. 2008;4(5):1061-8.

7. el-Mesallamy H, Suwailem S, Hamdy N. Evaluation of C-reactive protein, endothelin-1, adhesion molecule(s), and lipids as inflammatory markers in type 2 diabetes mellitus patients. Mediators Inflamm. 2007;2007:73635.

8. Kienitz T, Quinkler M. Testosterone and blood pressure regulation. Kidney Blood Press Res. 2008;31(2):71-9.

9. Kumanov P, Tomova A, Kirilov G. Testosterone replacement therapy in male hypogonadism is not associated with increase of endothelin-1 levels. Int J Androl. 2007;30(1):41-7.

10. Stow LR, Jacobs ME, Wingo CS, Cain BD. Endothelin-1 gene regulation. FASEB J. 2011;25(1):16-28.

11. Sokolova LK, Belchina YuB, Pushkarev VV, Cherviakova SA Vatseba TS, Kovzun OI, et al. The blood level of endothelin-1 in diabetic patients depending on the characteristics of the disease. Mezhdunarodnyi Endokrinologicheskii Zhurnal. 2020;16(30):204-8.

12. Davenport AP. Endothelin. Pharmacol Rev. 2016;68(2):357-418.

13. Thompson J, Khalil RA. Gender differences in the regulation of vascular tone. Clin Experim Pharmacol Physiol. 2003;30(1-2):1-15.

14. Scovell J, Ramasamy R, Kovac JR. A critical analysis of testosterone supplementation therapy and cardiovascular risk in elderly men. Can Urol Assoc J. 2014;8(5-6): E356-7.

15. Corona G, Rastrelli G, Monami M, Guay A, Buvat J, Sforza A, et al. Hypogonadism as a risk factor for cardiovascular mortality in men: a meta-analytic study. Eur J Endocrinol. 2011;165(5):687-701.

16. Muraleedharan V, Marsh H, Kapoor D, Channer KS, Jones TH. Testosterone deficiency is associated with increased risk of mortality and testosterone replacement improves survival in men with type 2 diabetes. Eur J Endocrinol. 2013;169(6):725-33.
17. Pastuszak AW, Kohn TP, Estis J, Lipshultz LI. Low plasma testosterone is associated with elevated cardiovascular disease biomarkers. J Sex Med. 2017;14(9):1095-103.

18. Sanchez E, Pastuszak AW, Khera M. Erectile dysfunction, metabolic syndrome, and cardiovascular risks: facts and controversies. Trans Androl Urol. 2017;6(1):28-36.

(Надійшла до редакиії 13.09.2020р.)

\section{Уровень эндотелина-1 и тестостерона в крови больных сахарным диабетом 1-го и 2-го типов}

\section{Е.В. Лучицкий, Л.К. Соколова, В.Е. Лучицкий, Ю.Б. Бельчина, Г.А. Зубкова, С.А. Червякова, В.М. Рыбальченко, В.В. Пушкарев, Т.С. Вацеба, И.И. Складанная, В.М. Пушкарев}

ГУ «Институт эндокринологии и обмена веществ им. В.П. Комиссаренко НАМН Украины»

Резюме. С сахарным диабетом связана эндотелиальная дисфункция (ЭД) - одно из ключевых патологических событий в развитии хронических диабетических осложнений. Важным эффектом ЭД является то, что она приводит к увеличению продукции и биологической активности эндотелина (ЕT). ЕТ-1, который вырабатывается в основном в эндотелии, является основной сердечно-сосудистой изоформой эндотелиновой системы. Сахарный диабет - одно из заболеваний, связанных с патологически повышенным уровнем ЕТ. Получены доказательства того, что андрогены могут играть существенную роль в определении специфического для пола артериального давления. Мужчины имеют более высокий риск развития ишемической болезни сердца или гипертонии по сравнению с женщинами в пременопаузе Цель - определение концентрации эндотелина-1 и тестостерона в крови больных сахарным диабетом 1-го и 2-го типов с различным индексом массы тела и в разном возрасте. Методы. Уровень ЕТ-1 оценивали методом ИФА у 103 человек: 17 здоровых лиц и 86 пациентов с диабетом первого (СД1) и второго (СД2) типов. Для определения концентрации ЕТ-1 использовали набор Endotelin (1-21) EIA. Общий тестостерон (Т) определяли с помощью набора ElA-1559. Результаты. У всех пациентов с диабетом уровень ЕТ-1 в крови был выше, чем у контрольной группы. Разница в количестве ET-1 в крови пациентов между 1 и 2 типами диабета была недостоверной. Уровень ЕТ-1 у мужчин был выше, чем у женщин в среднем на 37\%. В группе с большим индексом массы тела количество ЕТ-1 было выше на 71\%, а Т — ниже на 25\%. Уровень ЕT-1 в возрастной группе до 50 лет был ниже, чем в старшей группе для обоих типов диабета (123\% для СД1 и 148\% для СД2), а количество Т у больных СД2 - выше почти на 20\%. В группе больных СД2 с уровнем Т<3 нг/мл концентрация ЕТ-1 в крови была выше, чем у больных с уровнем Т>3 нг/мл (соответственно 0,550 фмоль/мл и 0,392 фмоль/мл). Выводы. У мужчин, больных сахарным диабетом 2-го типа с ожирением наблюдается повышение концентрации эндотелина-1, и снижение уровня общего тестостерона. Эти показатели, вероятно, непосредственно 
Оригінальні дослідження

не связаны с содержанием гликированного гемоглобина. С возрастом уровень эндотелина-1 в крови у больных сахарным диабетом растет, а уровень общего тестостерона снижается. Эти процессы могут быть взаимосвязанными. Концентрация эндотелина-1 в крови у мужчин, больных сахарным диабетом обоих типов достоверно выше, чем у женщин.

Ключевые слова: сахарный диабет, эндотелиальная дисфункция, эндотелин-1, тестостерон.

\section{The level of endothelin-1 and testosterone in the blood of patients with type 1 and type 2 diabetes}

\author{
Ye.V. Luchytskyi, L.K. Sokolova, V. Ye. Luchytskyi, \\ Y.B. Belchina, G.A. Zubkova, S.A. Cherviakova, \\ V.M. Rybalchenko, V.V. Pushkarev, T.S. Vatseba, \\ I.I. Skladanna, V.M. Pushkarev \\ SI «V.P. Komisarenko Institute of Endocrinology and Metabolism of the \\ National Academy of Medical Sciences of Ukraine»
}

\begin{abstract}
Endothelial dysfunction (ED) is one of the key pathological events in the development of chronic diabetic complications and is associated with diabetes mellitus. An important effect of ED is that it increases the production and biological activity of endothelin (ET). ET-1, which is produced primarily in the endothelium, is the main cardiovascular isoform of the endothelin system. Diabetes mellitus is one of the diseases associated with pathologically elevated ET levels. There is evidence that androgens may play a significant role in determining gender-specific blood pressure. Men have a higher risk of developing coronary heart disease or hypertension compared to premenopausal women. Aim of the study was to determine the concentration of endothelin-1 and testosterone in the blood of patients with type 1 and type 2 diabetes with different body mass index and different age categories. Methods. ET-1 levels were determined with ELISA in 103 people: 17 healthy persons and 86 patients with type 1 (T1D) and type 2 diabetes (T2D). The Endotelin (1-21) EIA kit was used to determine the ET-1 concentration. Testosterone ( $T$ ) was determined using the ElA-1559 kit. Results. All diabetic patients had higher ET-1 blood levels than controls. The difference in the amount of ET-1 in the blood of patients between types I and || diabetes was insignificant. ET-1 levels were higher in men than in women by an average of $37 \%$. In the group with a higher body mass index, ET-1 was 71\% higher, and T was 25\% lower The ET-1 level in the age group under 50 was lower than in the older group for both types of diabetes (123\% for T1D and 148\% for T2D), and the amount of T in T2D patients was almost 20\% higher. In the group of type 2 diabetes patients with a $T<3 \mathrm{ng} / \mathrm{ml}$, the concentration of ET-1 in the blood was higher than in patients with a $\mathrm{T}>3 \mathrm{ng} / \mathrm{ml}$ $0,550 \mathrm{fmol} / \mathrm{ml}$ vs $0,392 \mathrm{fmol} / \mathrm{ml}$, respectively. Conclusions. In obese men with type 2 diabetes mellitus, there is an increase in the
\end{abstract}

endothelin-1 concentration, and a decrease in the level of total testosterone. These indicators are probably not directly related to the content of glycated hemoglobin. With age, the level of endothelin-1 in the blood of diabetic patients increases, and the level of total testosterone decreases. These processes can be interrelated. The concentration of endothelin-1 in the blood in men with both types of diabetes is significantly higher than in women.

Keywords: diabetes mellitus, endothelial dysfunction, endothelin-1, testosterone.

Для цитування: Лучицький $\in B$, Соколова ЛК, Лучицький $B \in$, Бєльчина ЮБ, Зубкова ГА, Червякова СА, Рибальченко ВМ, Пушкарьов ВВ, Вацеба ТС, Складанна II, Пушкарьов ВМ. Рівні ендотеліну-1 та тестостерону в крові хворих на цукровий діабет 1-го та 2-го типів. Ендокринологія. 2020;25(4):291-296. DOI: 10.31793/16801466.2020.25-4.291.

Відомості про авторів: Євген Васильович Лучицький, д-р мед. наук, проф., ORCID: 0000-0003-4894-5110; Віталій Євгенович Лучицький, д-р мед. наук, старш. наук. співроб., ORCID: 0000-00023515-3264; Любов Костянтинівна Соколова, д-р мед. наук, старш. наук. співроб., ORCID: 0000-0003-0011-0106; Юлія Богуславівна Бєльчина, канд. мед. наук, e-mail: belchina_@ukr.net, ORCID: https:// orcid.org/0000-0002-4289-8977; Віктор Володимирович Пушкарьов, канд. біол. наук, ORCID: 0000-0001-5940-5510; Світлана Анатоліївна Червякова, ORCID: 0000-0002-6917-5736; Тамара Сергіївна Вацеба, канд. мед. наук, доцент, ORCID: https://orcid.org/0000-00017849-2242.; Галина Анатоліївна Зубкова, канд. біол. наук, ORCID: 0000-0002-9332-9248; Вікторія Михайлівна Рибальченко, ORCID: 0000-0002-9971-3526; Інна Іванівна Складанна, ORCID: 0000-00025590-3296; Володимир Михайлович Пушкарьов, д-р біол. наук, старш. наук. співроб., ORCID: 0000-0003-0347-7771.

Особистий внесок: Є.В. Лучицький, В.Є. Лучицький, Л.К. Соколова - ідея дослідження, дизайн дослідження, підбір та клінічне обстеження пацієнтів та чоловіків контрольної групи; С.А. Червякова, Ю.Б. Бєльчина, Т.С. Вацеба - збір і підготовка біоматеріалів; Г.А. Зубкова, В.М. Пушкарьов - первинний аналіз та обробка отриманих даних, написання статті; В.М. Рибальченко, І.І. Складанна, В.В. Пушкарьов - проведення лабораторних досліджень, оформлення статті, переклад.

Фінансування: дослідження проводилось за планом науководослідних робіт ДУ «нститут ендокринології та обміну речовин ім. В.П. Комісаренка НАМН України», на тему: «Вивчити особливості серцево-судинної системи та формування коронарного атеросклерозу у хворих на цукровий діабет», № державної реєстрації: $0118 \cup 002163$.

Декларація з етики: Автори заявили, що немає конфлікту інтересів або фінансових зобов'язань. 